Article

\title{
The Performance of Five Willow Cultivars under Different Pedoclimatic Conditions and Rotation Cycles
}

\author{
Werther Guidi Nissim ${ }^{1,2}$, Benoit Lafleur ${ }^{1,3}$ and Michel Labrecque ${ }^{1, *}$ \\ 1 Institut de Recherche en Biologie Végétale, Université de Montréal and Montreal Botanical Garden, \\ Montréal, QC H1X 2B2, Canada; werther.guidinissim@unifi.it (W.G.N.); benoit.lafleur@uqat.ca (B.L.) \\ 2 Department of Agrifood Production and Environmental Science-University of Florence, Firenze 50144, Italy \\ 3 Forest Research Institute and Industrial Chair NSERC-UQAT-UQAM in Management of Sustainable Forest, \\ Université du Québec en Abitibi-Témiscamingue, Rouyn-Noranda, QC J9X 5E4, Canada \\ * Correspondence: michel.labrecque@umontreal.ca; Tel.: +1-514-872-1862
}

Received: 1 May 2018; Accepted: 11 June 2018; Published: 13 June 2018

\begin{abstract}
A plant's genotype, their environment, and the interaction between them influence its growth and development. In this study, we investigated the effect of these factors on the growth and biomass yield of willows in short-rotation coppice (SRC) under different harvesting cycles (i.e., two- vs. three-year rotations) in Quebec (Canada). Five of the commercial willow cultivars most common in Quebec, (i.e., Salix $\times$ dasyclados Wimm. 'SV1', Salix viminalis L. '5027', Salix miyabeana Seeman 'SX61', 'SX64' and 'SX67') were grown in five sites with different pedoclimatic conditions. Yield not only varied significantly according to site and cultivar, but a significant interaction between rotation and site was also detected. Cultivar ' 5027 ' showed significantly lower annual biomass yield in both two-year (average $10.8 \mathrm{tha}^{-1}$ year ${ }^{-1}$ ) and three-year rotation (average $11.2 \mathrm{t} \mathrm{ha}^{-1}$ year $^{-1}$ ) compared to other cultivars (15.2 $\mathrm{t} \mathrm{ha}^{-1}$ year $^{-1}$ and $14.6 \mathrm{t} \mathrm{ha}^{-1}$ year $^{-1}$ in two- and three-year rotation, respectively). Biomass yield also varied significantly with rotation cycle, but the extent of the response depended upon the site. While in some sites the average productivity of all cultivars remained fairly constant under different rotations (i.e., 17.4 vs. $16 \mathrm{t} \mathrm{ha}^{-1}$ year $^{-1}$ in two- and three-year rotation, respectively), in other cases, biomass yield was higher in the two- than in the three-year rotation or vice versa. Evidence suggests that soil physico-chemical properties are better predictors of willow SRC plantation performance than climate variables.
\end{abstract}

Keywords: Salix; SRC; biomass; willow cultivars; environmental conditions

\section{Introduction}

Woody biomass is a renewable resource with multiple applications, and can be used as feedstock for pulp and paper production as well as by the energy or biofuel industry [1]. Short-rotation coppice (SRC) is a well-established plant production technique used to manage a broad variety of woody species, mostly for bioenergy purposes. This cropping system was defined in the late 1980s as a silvicultural approach based on short clear-felling cycles, which uses intensive cultural techniques with genetically superior planting material and often relies on coppice regeneration [2]. Since then, it has been applied to a number of species, including poplars [3], willows [4], eucalyptus [5], black locust [6], alders [7] and Leucaena spp. [8]. In the early years, SRC plantations were designed to be managed much like any other agricultural crop, by methods including tilling, fertilization, weed and pest control, and irrigation [9]. However, concerns were raised about the need to reduce its footprint on the environment while maintaining economic profitability [10]. This has led to management models that rely on less external input, often by recycling different types of waste, including ash [11], sewage 
sludge [12,13], pig slurry [14] and wastewaters [15-17]. The productivity of SRC plantations relies heavily on the cultivar's genotypic characteristics, habitat-related factors and cultivation techniques. Along with poplar, willow SRC represents a very popular woody crop in temperate regions of North America and Eurasia. In fact, willow SRCs have been shown to be one of the best-suited biomass crops for many Canadian regions, because under optimal conditions they can achieve very high biomass yields (on average $21 \mathrm{t} \mathrm{ha}^{-1}$ year $^{-1}$ of dry biomass for the most productive cultivar) [18], although yields are highly dependent on genotypic characteristics, soil fertility, climate, and crop management [19]. A recent study conducted to determine which set of soil, climatic conditions, and cultivars are responsible for greater willow SRC yields in eastern Canada showed that both geographic location and cultivar play a significant role in determining annual yields. In particular, biomass yield was positively correlated to some climatic (i.e., average annual temperature, total annual precipitation, average growing season temperature, average growing season precipitation, and degree days) and soil $(\mathrm{pH}$, extractible $\mathrm{P})$ factors and negatively affected by others (e.g., soil clay concentration) [20]. However, this study was conducted over a single rotation. Furthermore, other studies report higher average annual biomass yield in four-year rotation willow plantations compared to those in a three-year cycle [18]. In this context, it appears necessary to assess the response of different willow cultivars grown over several rotations and under different rotation lengths. Because it is an early successional species, willow shows fast juvenile growth and rapid adjustments in leaf area and shoot morphology in response to environmental conditions and management practices [21-23]. This means that in dense plantations, the maximum mean annual increment (MAI) in biomass yield is reached at an early stage. However, available information about this aspect is still inconclusive. Some studies have reported the highest MAI in willow grown in Sweden at a density of 20.000 plants ha $^{-1}$ and managed with 4-year rotation harvesting [24]. Therefore, in order to identify optimal rotation length in willow SRC, both cultivar characteristics and environmental parameters must be considered along with the principles determining the dynamics of a population under inter-plant competition.

The aim of the current study was: (i) to assess the response of several willow cultivars in SRC to different rotations; and (ii) to highlight which set of environmental parameters play a major role in determining the yield of different willow cultivars.

\section{Materials and Methods}

\subsection{Experimental Sites}

This study was carried out over a three-year period (2015-2016-2017) at five sites in southern Quebec, Canada, located along a climatic gradient. Prior to plantation establishment, each site had distinct soil properties (Table 1).

Table 1. Soil Physical and Chemical Characteristics at the Time of Establishment for Five short-rotation coppice (SRC)-Willow Plantations.

\begin{tabular}{|c|c|c|c|c|c|c|c|c|c|c|c|}
\hline Site & $\mathrm{pH}$ & $\begin{array}{c}\text { OM } \\
\%\end{array}$ & $\mathbf{P}$ & \multicolumn{2}{|c|}{$\left(\mathrm{kg} \mathrm{ha}^{-1}\right)$} & $\mathrm{Mg}$ & Sand & $\begin{array}{c}\text { Silt } \\
\%\end{array}$ & Clay & Texture & Soil Type \\
\hline Beloeil & 7.3 & 4.2 & 31 & 729 & 7570 & 2490 & 10 & 40 & 50 & Silty clay & Gleysols \\
\hline Boisbriand & 6.9 & 4 & 21 & 166 & 4935 & 1120 & 31 & 33 & 36 & Clayey loam & Brunisols \\
\hline La Morandière & 5.6 & 2.9 & 20 & 410 & 2796 & 1261 & 1 & 36 & 63 & Clay & Luvisols \\
\hline La Pocatière & 6.1 & 5.6 & 101 & 475 & 5889 & 1138 & 20 & 31 & 49 & Clay & Gleysols \\
\hline St-Siméon & 5.2 & 2.1 & 50 & 155 & 1662 & 72 & 60 & 20 & 20 & Sandy loam & Brunisols \\
\hline
\end{tabular}

Soil texture was determined by granulometric analysis; $\mathrm{P}, \mathrm{K}, \mathrm{Ca}$, and $\mathrm{Mg}$ were extracted by Melich-3 digestion and determined using inductively coupled plasma mass spectrophotometry (ICP-MS); OM organic matter [20].

The Beloeil $\left(45^{\circ} 35^{\prime} 24^{\prime \prime} \mathrm{N}-73^{\circ} 13^{\prime} 48^{\prime \prime} \mathrm{W}\right)$ and Boisbriand $\left(45^{\circ} 35^{\prime} 24^{\prime \prime} \mathrm{N}-73^{\circ} 13^{\prime} 48^{\prime \prime} \mathrm{W}\right)$ sites showed the highest $\mathrm{pH}$ values (7.1 on average), as well as high organic matter (OM) $(4.1 \%)$ and $\mathrm{Ca}, \mathrm{Mg}, \mathrm{K}$ concentrations, whereas the La Morandière $\left(48^{\circ} 40^{\prime} 12^{\prime \prime} \mathrm{N}-77^{\circ} 36^{\prime} 00^{\prime \prime} \mathrm{W}\right)$ and St-Siméon $\left(48^{\circ} 04^{\prime} 12^{\prime \prime} \mathrm{N}-65^{\circ} 33^{\prime} 36^{\prime \prime} \mathrm{W}\right.$ ) sites showed the lowest $\mathrm{pH}$ values (5.4 on average) and OM concentration 
(2.5\%), as well as lower $\mathrm{Ca}, \mathrm{Mg}$ and $\mathrm{K}$ concentrations. The La Pocatière site $\left(47^{\circ} 21^{\prime} 36^{\prime \prime} \mathrm{N}-70^{\circ} 01^{\prime} 48^{\prime \prime}\right.$ $\mathrm{W})$ showed intermediate properties and, compared to the other sites, had the highest OM $(5.6 \%)$ and P concentrations. Sites also differed in soil texture; the La Morandiere site is clay Luvisol, whereas the St-Siméon site is a sandy loam Brunisol. More details on soil properties are reported in Lafleur et al. [20].

\subsection{Willow Varieties and Experimental Setup}

The experimental sites were all located on former agricultural farmland. In the fall of 2010, the soil was prepared by ploughing, and disc harrowing was performed the following spring prior to planting. One-year-old dormant cuttings $(0.20-0.25 \mathrm{~m})$ were planted in the spring of 2011. Plant density at establishment was 18,500 cuttings ha ${ }^{-1}(1.80 \mathrm{~m}$ between rows and $0.30 \mathrm{~m}$ within each row). Five of the willow commercial cultivars most common in Quebec were selected, including 'SV1' (Salix $\times$ dasyclados Wimm.), '5027' (Salix viminalis L.), 'SX61', 'SX64' and 'SX67' (Salix miyabeana Seeman). The five willow cultivars were arranged in a complete randomized block experimental design with four replicates for each cultivar (total 20 plots per site, 100 plants per plot per each cultivar). Throughout the trial, weeding was performed manually in willow rows, and mechanically between rows. No chemical control of weeds, pests or diseases was performed during the trial. All plots in all sites were harvested (cut back) at the end of the first growing season. Since high mortality was recorded at the La Morandière site in 2011, the site was replanted in 2012. The following spring (2012), mineral fertilizer was applied, supplying $100 \mathrm{~kg} \mathrm{ha}^{-1}$ of $\mathrm{N}, 100 \mathrm{~kg} \mathrm{ha}^{-1}$ of $\mathrm{P}_{2} \mathrm{O}_{5}$. While $\mathrm{N}$ was supplied to all sites, only those showing less than $100 \mathrm{~kg} \mathrm{ha}^{-1}$ of $\mathrm{P}$ prior to planting received $\mathrm{P}_{2} \mathrm{O}_{5}$ fertilizer (e.g., the La Pocatière site received none). Plants were harvested from all sites in 2014 when stems were three (S3) and roots four (R4) years old respectively (except for the La Morandière site, were roots were three years old). Data related to the first rotation are described in Lafleur et al. [20]. After the first harvest, each site was split into biannual (S2R6) and triennial (S3R7) rotation cycles with blocks 1 and 2 harvested in 2016 (biannual) and blocks 3 and 4 harvested in 2017 (triennial). Plants were harvested at the end of the growing season, that is, in November.

\subsection{Measurement and Sampling}

At the end of the growing season of each rotation (2016 and 2017) the height and diameter $(0.2 \mathrm{~m}$ above ground) of the main stem were measured on nine randomly selected plants per block for each species in each site. Plants were randomly selected within the two central rows in order to avoid edge effect. The growth rates were expressed as annual diameter and height increments by dividing the value measured by the age of the stems. In addition, after leaf drop, the same plants were harvested and weighed in the field using an electronic scale. To evaluate dry matter of willow aboveground biomass, the whole green stem samples collected from the field were oven-dried at $80^{\circ} \mathrm{C}$ (to constant mass) before being reweighed. Annualized biomass yield was calculated by dividing plantation density as re-evaluated at the end of each growing season by the age of the plants.

\subsection{Meteorological Conditions}

The climatic conditions at different experimental sites are shown in Figure 1. According to the nearest weather station for each site, from 2015 to 2017, La Morandière was the site recording the lowest average annual temperature (i.e., $1.3^{\circ} \mathrm{C}$ ) and the lowest rainfall $(579 \mathrm{~mm})$, whereas Beloeil showed the highest average annual temperature (i.e., $7.3^{\circ} \mathrm{C}$ ) and St-Siméon the highest annual rainfall $(1143 \mathrm{~mm})$. During the growing season (i.e., May to September), average temperatures varied between $13.5^{\circ} \mathrm{C}$ (St-Siméon) and $18.8^{\circ} \mathrm{C}$ (Boisbriand), whereas total precipitation varied between $340 \mathrm{~mm}$ (La Pocatière) and $490 \mathrm{~mm}$ (St-Siméon). 


\section{Beloeil}

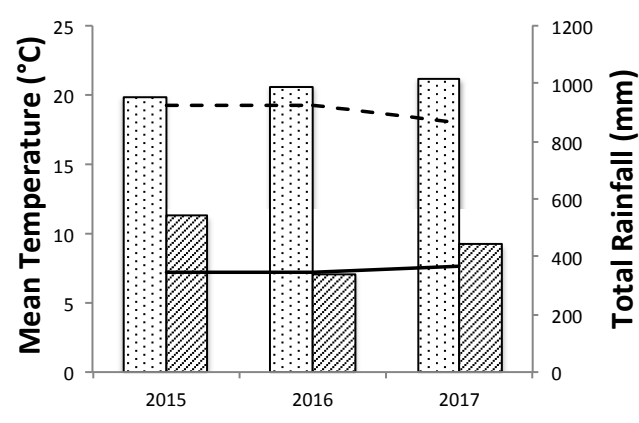

$\because$ Annual

Annual

La Morandière

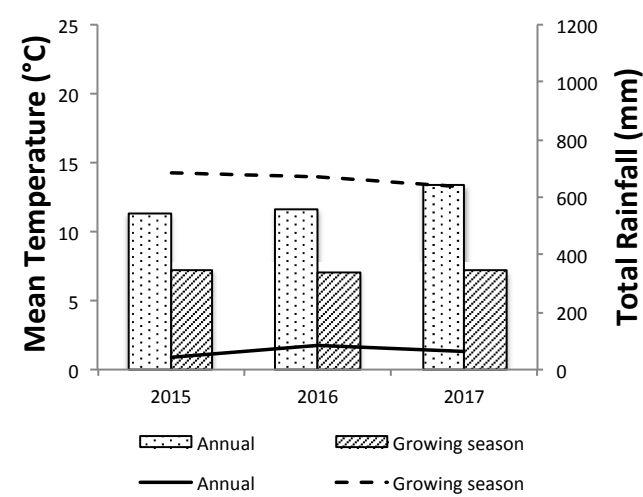

St-Siméon

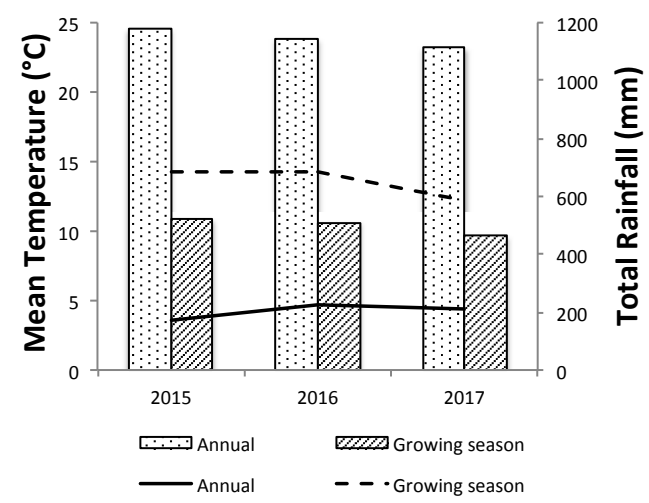

Boisbriand

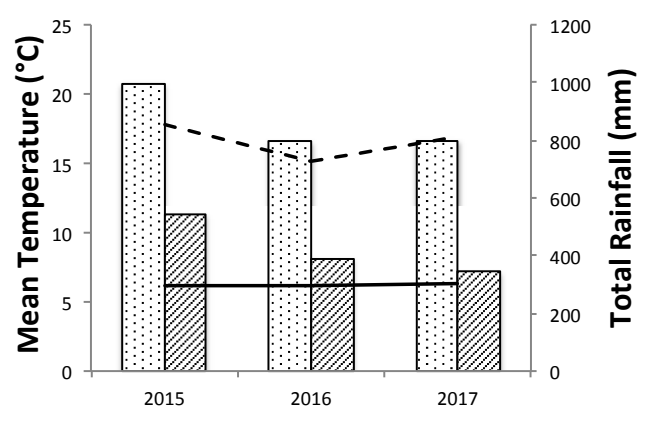

Cannual Growing season

- - Growing season

La Pocatière

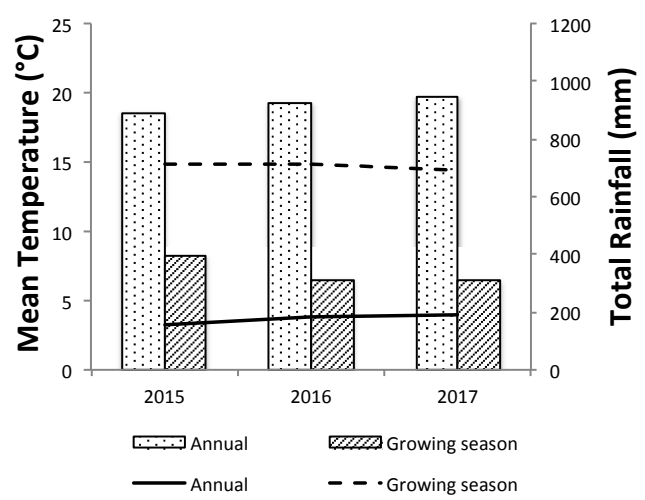

Figure 1. The mean temperature and rainfall on an annual basis and during the growing season (May-September 2015-2017) at different experimental sites. Bars represent annual precipitation and lines temperature.

\subsection{Data Analysis}

Within each rotation cycle, the differences in plant growth and biomass yield of the five cultivars in the five locations were assessed through two-way ANOVA tests followed by multiple comparisons of means according to Tukey's Honestly Significant Difference (HSD). A 5\% significance level was adopted for identifying significant treatment effects (i.e., cultivar, site, cultivar $\times$ site). Subsequently, a regression tree approach was used to predict, independently for the two- and three-year rotations, plant height and diameter annual increment and annual yield at the site level from climate and soil variables. Regression trees function by partitioning a dataset into increasingly homogenous subsets. 
This approach was selected because it is non-parametric, can account for non-linear relationships between variables, and tends to be robust in regard to errors in both the independent and dependent variables [25]. Regression trees were carried out using JMP 10.0 (SAS, 2012).

\section{Results}

\subsection{Plant Growth and Biomass Yield}

The growth of willow plants varied according to cultivar, site and the interaction between these two factors. For the two-year rotation cycle, the diameter growth rate was significantly influenced by both the cultivar $(p<0.0001)$ and the site $(p<0.0001)$ (Figure 2$)$. In particular, cultivars of the S. miyabeana group (i.e., 'SX61', 'SX64' and 'SX67') showed the highest diameter growth rates (average $14.1 \mathrm{~mm}$ year ${ }^{-1}$ ) compared to 'SV1' and '5027' (10.6 $\mathrm{mm}$ year $^{-1}$ ). The highest diameter growth rates (average $14.4 \mathrm{~mm}_{\text {year }}{ }^{-1}$ ) were recorded at two specific sites (i.e., La Pocatière and Beloeil) for all cultivars, whereas for cultivar S. viminalis '5027', the most productive site was in La Morandière, with an average growth rate of $12.0 \mathrm{~mm}_{\text {year }}{ }^{-1}$. On the other hand, for the three-year rotation, ANOVAs showed significant differences only among cultivars, whereas no significant difference was found among the sites (Figure 2). In particular, we found that although diameter growth was reduced compared to the two-year rotation, at all sites the $S$. miyabeana cultivars showed higher growth rates (average $8.0 \mathrm{~mm}$ year ${ }^{-1}$ ) compared to '5027' (average $6.1 \mathrm{~mm}^{\text {year }}{ }^{-1}$ ) and 'SV1', which showed intermediate values $\left(7.0 \mathrm{~mm}_{\text {year }}{ }^{-1}\right)$.

Height increment rate of the willow stems submitted to a two-year rotation was influenced by site $(p<0.0001)$, cultivar $(p<0.0001)$ and the interaction between them (Figure 3). Thus, the tallest willow cultivars were 'SX61', 'SV1', 'SX67' and 'SX64' at Beloeil (average $243 \mathrm{~cm}$ year ${ }^{-1}$ ), 'SX61' and 'SX64' at Boisbriand (average $230 \mathrm{~cm}_{\text {year }}^{-1}$ ), 'SX64' at La Morandière (average $162 \mathrm{~cm}$ year ${ }^{-1}$ ), 'SX61' at La Pocatière (average $255 \mathrm{~cm}_{\text {year }}{ }^{-1}$ ), and 'SX61' and 'SX67' at St-Siméon (average $235 \mathrm{~cm} \mathrm{year}^{-1}$ ). On the other hand, except at La Morandière (122 cm year $\left.{ }^{-1}\right)$, cultivar '5027' showed the poorest performance (average $154 \mathrm{~cm}$ year $^{-1}$ ). In the three-year rotation, the rate of height increment of willow stems varied according to cultivar $(p<0.0001)$, and, to a lesser extent, site $(p=0.0332)$, although the average increment values were lower than in the two-year rotation. In this case, 'SX61' was the best performing cultivar in all sites (average $137 \mathrm{~cm}_{\text {year }}{ }^{-1}$ ) and '5027' the worst performing cultivar (average $92 \mathrm{~cm}$ year $^{-1}$ ). For all cultivars, the La Pocatière site (average $141 \mathrm{~cm}_{\text {year }}{ }^{-1}$ ) recorded significant higher stem height increments than at La Morandière.

With respect to biomass yield, we observed significant differences according to site $(p<0.0001)$ and cultivar $(p<0.0001)$, as well as a significant interaction between rotation and site $(p<0.0001)$. In particular, in all locations, cultivar '5027' showed a significantly lower annual biomass yield in both two-year (average $10.8 \mathrm{t} \mathrm{ha}^{-1}$ year $^{-1}$ ) and three-year rotations (average $11.2 \mathrm{t} \mathrm{ha}^{-1}$ year $^{-1}$ ), compared with the other cultivars, which on average showed a biomass yield ranging from $15.2 \mathrm{tha}^{-1}$ year $^{-1}$ to $14.6 \mathrm{t} \mathrm{ha}^{-1}$ year $^{-1}$ in two- and three-year rotations respectively. (Figure 4). The most productive site was La Pocatière, with $30.9 \mathrm{t} \mathrm{ha}^{-1}$ year $^{-1}$ and $21 \mathrm{t} \mathrm{ha}^{-1}$ year $^{-1}$ in the two- and three-year rotations respectively, whereas the least productive site was La Morandière, where average biomass yield ranged between $4.6 \mathrm{t} \mathrm{ha}^{-1}$ year $^{-1}$ and $5.5 \mathrm{t} \mathrm{ha}^{-1}$ year $^{-1}$ in the two- and three-year rotations respectively. Intriguingly, biomass yield also varied significantly with rotation cycle, but the extent of the response was site-dependent (Table 2). Thus, although at Beloeil the average biomass yield of all cultivars remained fairly constant under different rotations (i.e., 17.4 vs. $16 \mathrm{t} \mathrm{ha}^{-1}$ year $^{-1}$ in two- and three-year rotations respectively), in other cases, biomass yield was higher in two-year than in three-year rotation (La Pocatière and St-Siméon) or the opposite, higher in three-year than in two-year rotation (Boisbriand and La Morandière). 

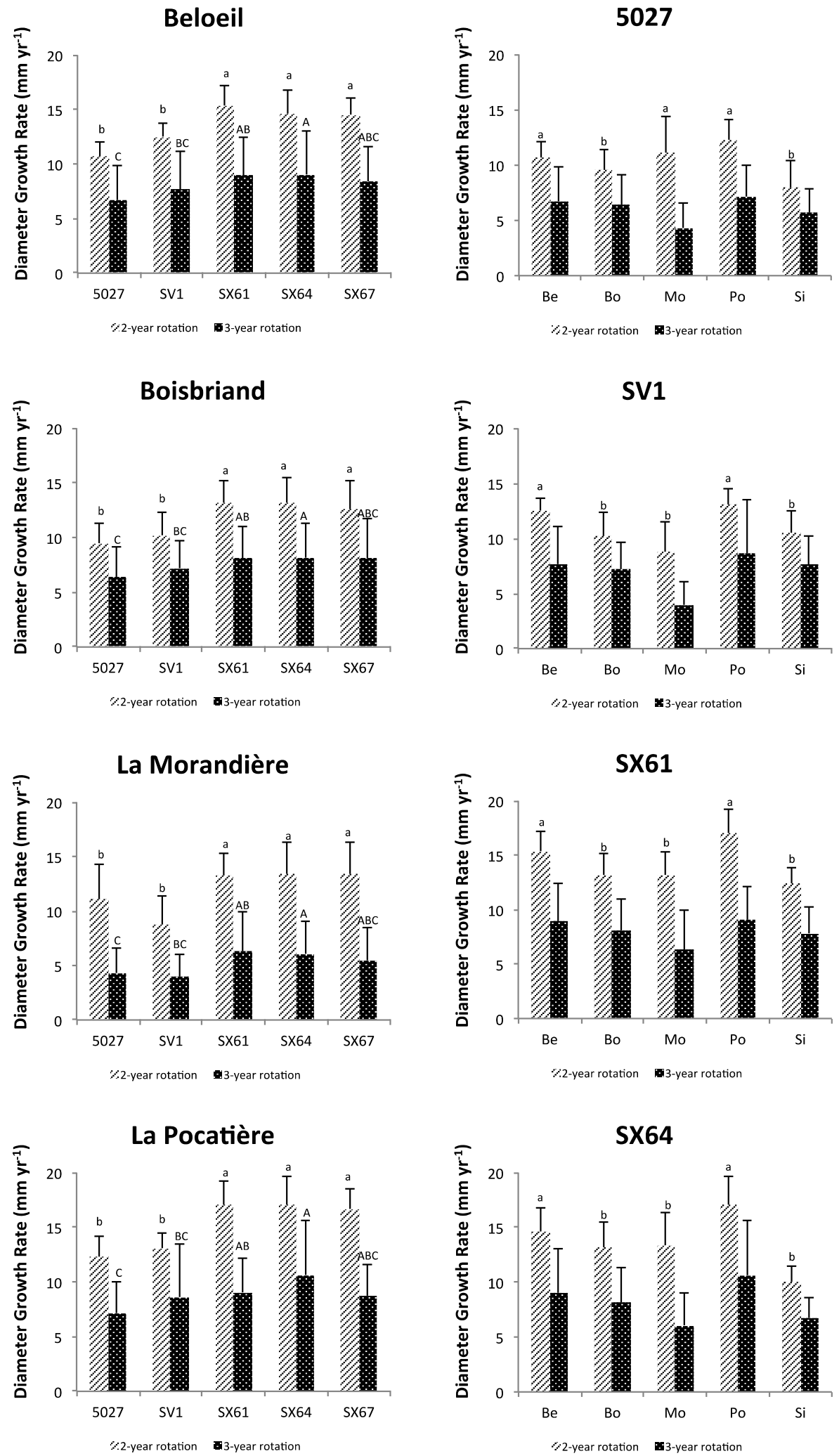

Figure 2. Cont. 

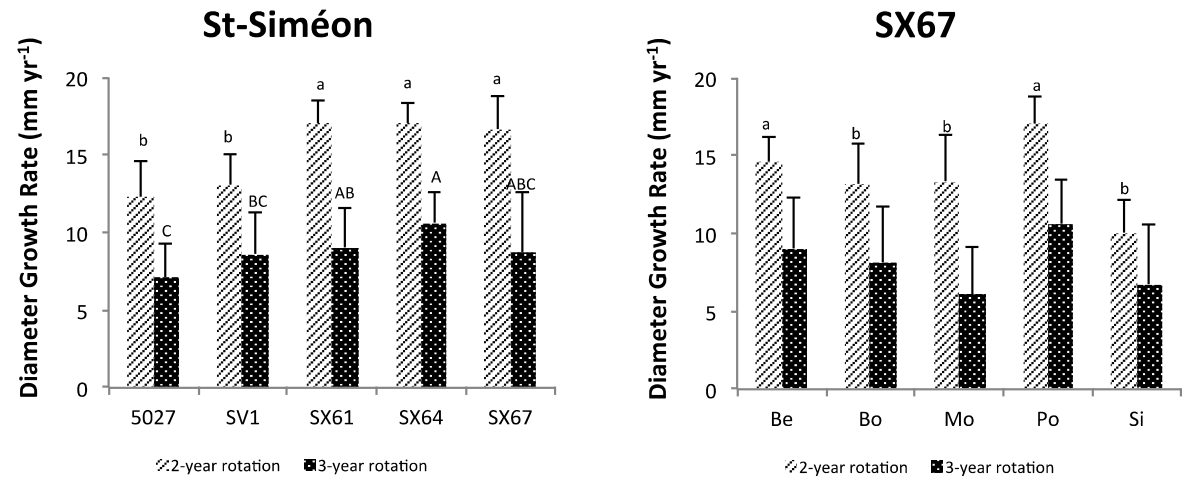

Figure 2. Stem diameter growth rates of willow stems under different rotation cycles. Values are means ( $n=9$; standard deviation on the top of each bar) for each site $(\mathrm{Be}=$ Beloeil; $\mathrm{Bo}=$ Boisbriand; $\mathrm{Mo}=\mathrm{La}$ Morandière; $\mathrm{Po}=\mathrm{La}$ Pocatière, $\mathrm{Si}=$ St-Siméon) and cultivar. A 5\% significance level was adopted for identifying significant treatment effects according to Tukey's HDS test. Lowercase letters were used to highlight significant difference in two-year rotation. Capital letters identify significant differences in the three-year rotation.
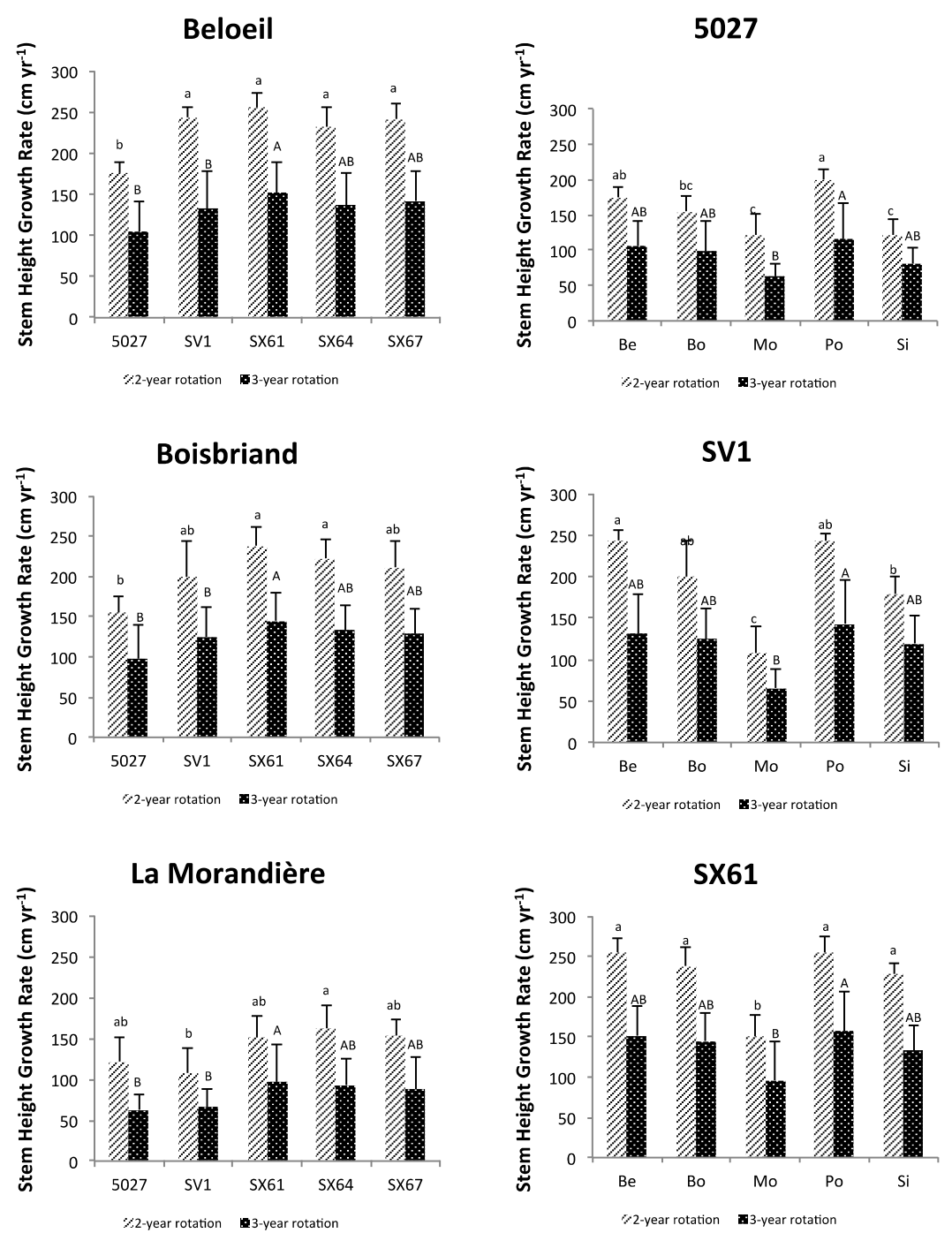

Figure 3. Cont. 

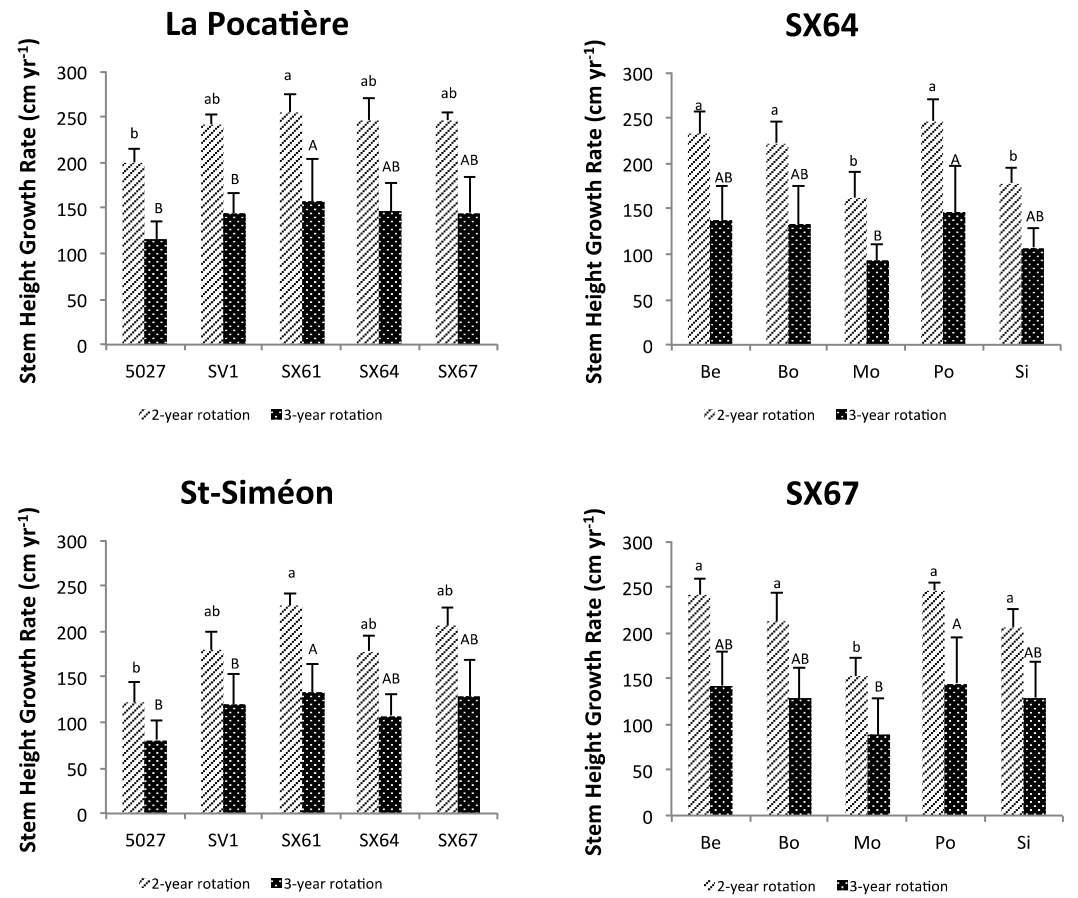

Figure 3. Stem height growth rates of willow stems under different rotation cycles. Values are means $(n=9$; $\mathrm{SD}$ on the top of each bar) for each site $(\mathrm{Be}=$ Beloeil; $\mathrm{Bo}=$ Boisbriand; $\mathrm{Mo}=\mathrm{La}$ Morandière; $\mathrm{Po}=\mathrm{La}$ Pocatière, $\mathrm{Si}=\mathrm{St}$-Siméon) and cultivar. A 5\% significance level was adopted for identifying significant treatment effects according to Tukey's HDS test. Lowercase letters were used to highlight significant difference in two-year rotation Capital letters identify significant differences in the three-year rotation.
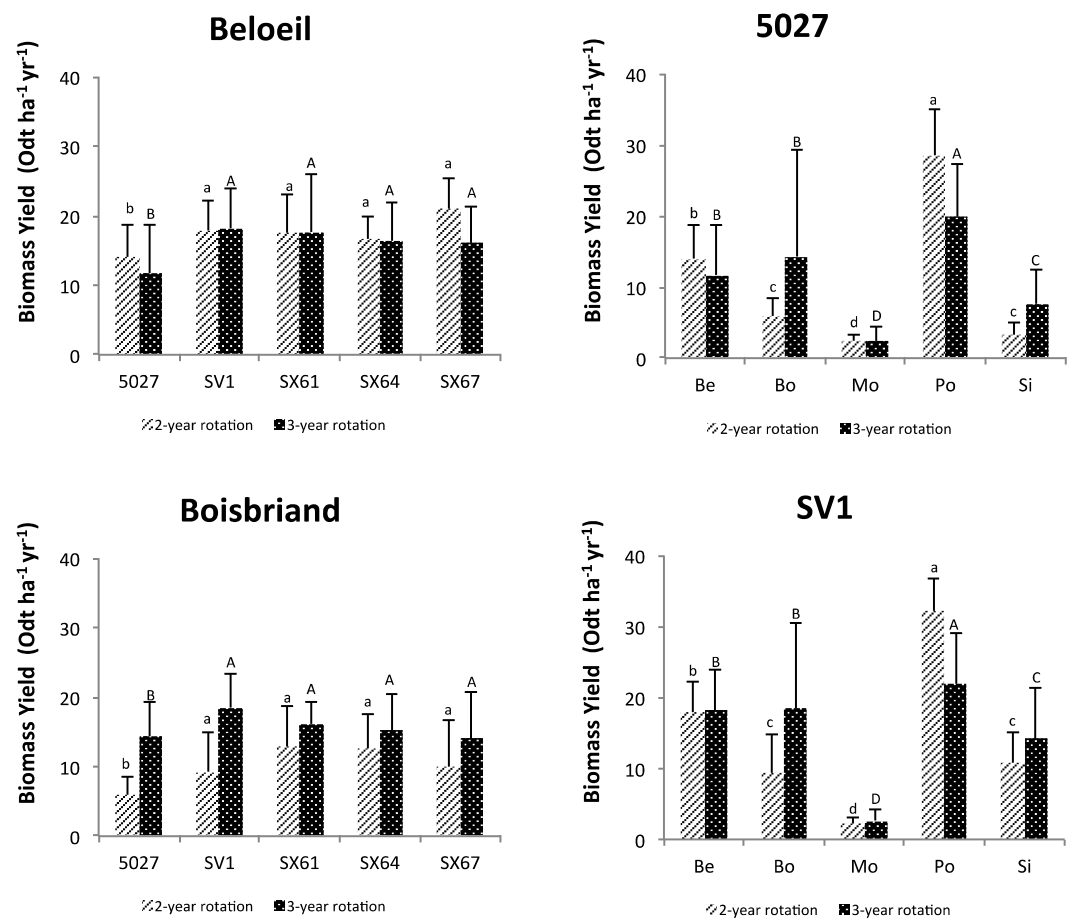

Figure 4. Cont. 

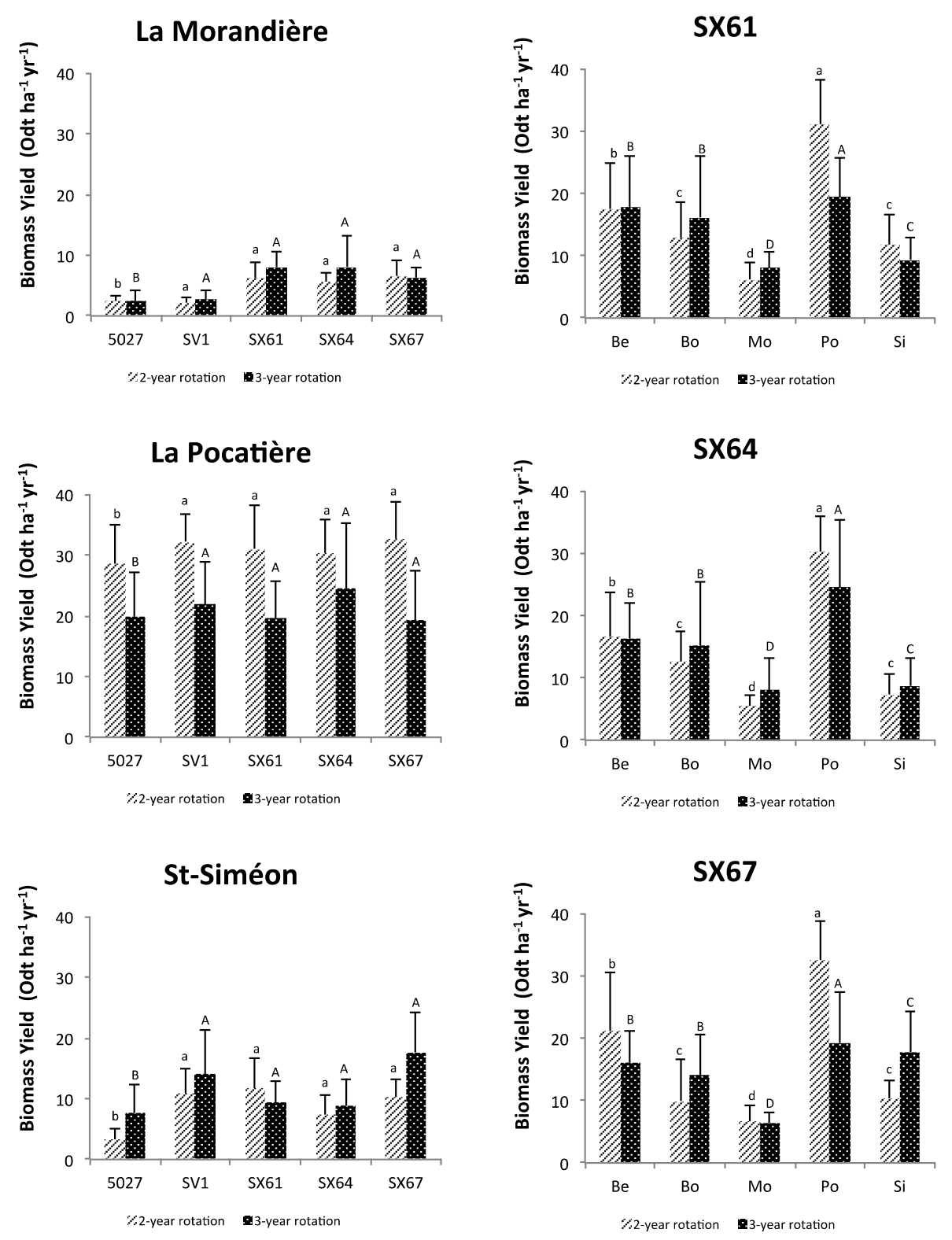

Figure 4. Annual biomass yield of willow plants under different rotation cycles. Values are means $(n=9$; $\mathrm{SD}$ on the top of each bar) for each site $(\mathrm{Be}=$ Beloeil; $\mathrm{Bo}=$ Boisbriand; $\mathrm{Mo}=\mathrm{La}$ Morandière; $\mathrm{Po}=\mathrm{La}$ Pocatière, $\mathrm{Si}=$ St-Siméon) and cultivar. A 5\% significance level was adopted for identifying significant treatment effects according to Tukey's HDS test. Lowercase letters were used to highlight significant difference in two-year rotation. Capital letters identify significant differences in the three-year rotation. 
Table 2. Results of ANOVA tests describing the statistical significance of site, cultivar, and rotation on willow biomass yield.

\begin{tabular}{|c|c|c|c|c|c|}
\hline Source & Nparm & DF & DFDen & F Ratio & Prob. $>$ F \\
\hline Site & 4 & 4 & 50 & 99.0831 & $<0.0001$ \\
\hline Cultivar & 4 & 4 & 50 & 7.8034 & $<0.0001$ \\
\hline Site $\times$ Cultivar & 16 & 16 & 50 & 1.752 & 0.0668 \\
\hline Rotation & 1 & 1 & 50 & 0.0422 & 0.838 \\
\hline Site $\times$ Rotation & 4 & 4 & 50 & 9.9017 & $<0.0001$ \\
\hline Cultivar $\times$ Rotation & 4 & 4 & 50 & 0.3704 & 0.8286 \\
\hline Site $\times$ Cultivar $\times$ Rotation & 16 & 16 & 50 & 0.6305 & 0.8437 \\
\hline \multicolumn{6}{|c|}{ Least Square Mean } \\
\hline \multirow{2}{*}{ Site } & \multicolumn{5}{|c|}{ Rotation } \\
\hline & \multicolumn{3}{|c|}{ Two-year } & \multicolumn{2}{|c|}{ Three-year } \\
\hline Beloeil & 16.729656 & & A & 15.294729 & A \\
\hline Boisbriand & 9.270192 & & $\mathrm{~B}$ & 14.119425 & $\mathrm{~A}$ \\
\hline La Morandière & 4.1636872 & & $\mathrm{~B}$ & 4.8795649 & $\mathrm{~A}$ \\
\hline La Pocatière & 30.626091 & & $\mathrm{~A}$ & 20.151016 & $\mathrm{~B}$ \\
\hline La Pocatière & 10.681216 & & A & 7.98445 & B \\
\hline
\end{tabular}

The table highlights the interaction between site and rotation and their impact on biomass yield. Different letters between columns indicate significant differences $(p \leq 0.05)$ according to Tukey's HSD test.

\subsection{Relating Plant Height and Diameter Annual Increment and Annual Yield to Climate and Soil Variables}

Regression tree analyses conducted on the two-year rotation showed that along the pedoclimatic gradient, soil variables were more accurate than climate variables at predicting height and diameter annual increment and annual biomass yield than climate variables (Figure 5). With respect to both height and diameter annual increment (Figure $5 \mathrm{a}, \mathrm{b}$ ), soil $\mathrm{pH}$ and $\mathrm{OM}$ content best explained differences observed among sites, with sites with better annual increment having higher soil $\mathrm{pH}$ and OM content. Soil extractible $\mathrm{P}$ was the best predictor of annual biomass yield, and the next best predictor was mean annual temperature (Figure 5c). More specifically, higher extractible P and mean annual temperature were conducive to greater annual biomass yield. With respect to these predictors, the La Pocatière, Beloeil and Boisbriand sites showed the best performance. For the three-year rotation, regression tree analyses showed that soil extractible $\mathrm{P}$ and clay content were the best predictors of height annual increment (Figure 6a), whereas soil exchangeable $\mathrm{Ca}$, extractible $\mathrm{P}$ and $\mathrm{pH}$ were the best predictors of annual biomass yield (Figure 6c). More specifically, high soil $\mathrm{P}, \mathrm{Ca}, \mathrm{pH}$ and clay content were associated with sites with better performance. With respect to diameter increment, three-year mean annual temperature, followed by soil sand content, were the best predictors; high mean annual temperature and low sand content were related to better growth (Figure $6 \mathrm{~b}$ ). Taken together, these results strongly suggest that soil variables exerted a stronger effect than climate variables on plant growth for the three-year rotation. As was the case for the two-year rotation, the La Pocatière, Beloeil and Boisbriand sites showed the best performance with respect to these predictors. Soil physico-chemical properties therefore appeared better significant predictors of willow SRC plantation performance. 

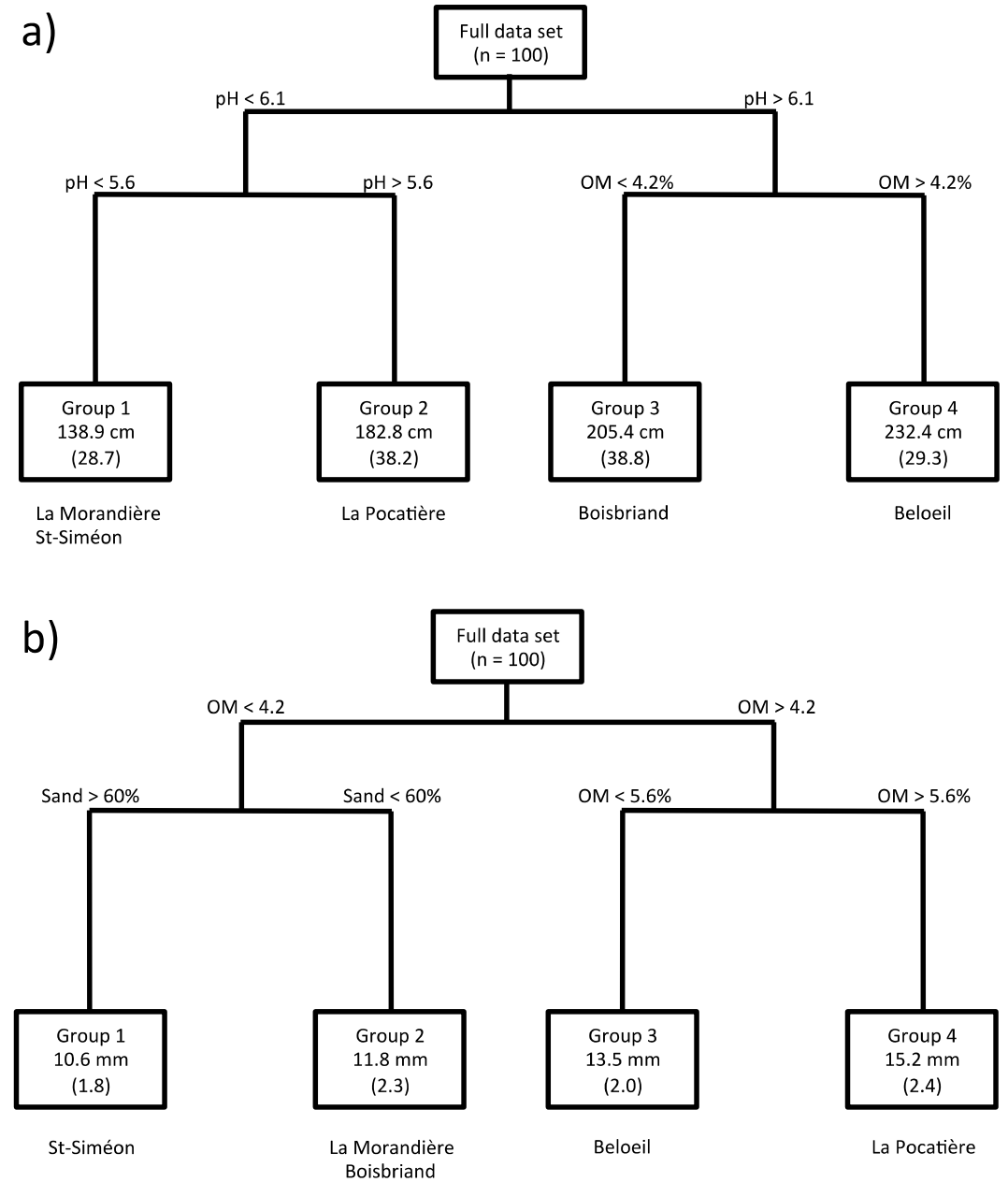

c)

Boisbriand
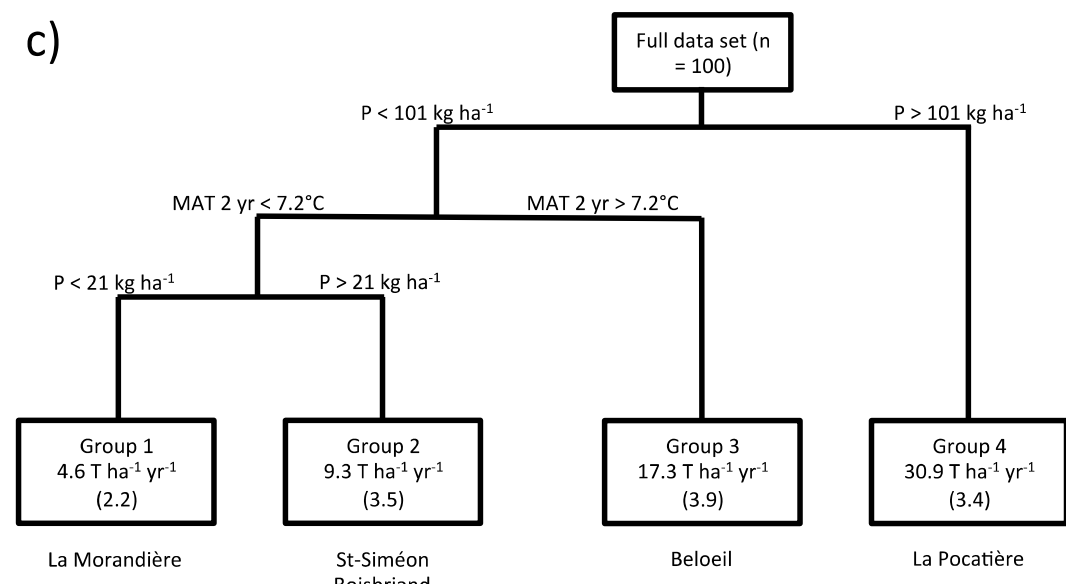

Figure 5. Regression tree model for stem height (a), stem diameter (b), and biomass yield (c) in the two-year rotation willow SRC. MAT, mean annual temperature; OM, soil organic matter; $\mathrm{P}$, soil extractible phosphorus; $\mathrm{pH}$, soil $\mathrm{pH}$; Sand, soil sand content. Splitting values are indicated along the branches, and boxes indicate terminal node mean ( \pm standard error). 
a)

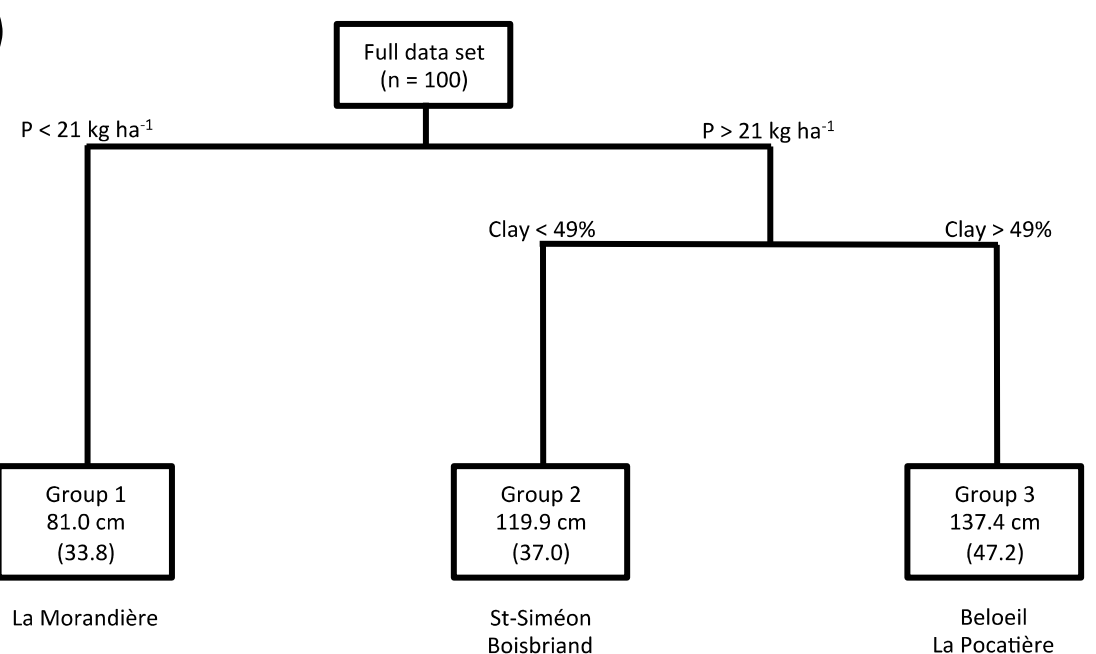

b)
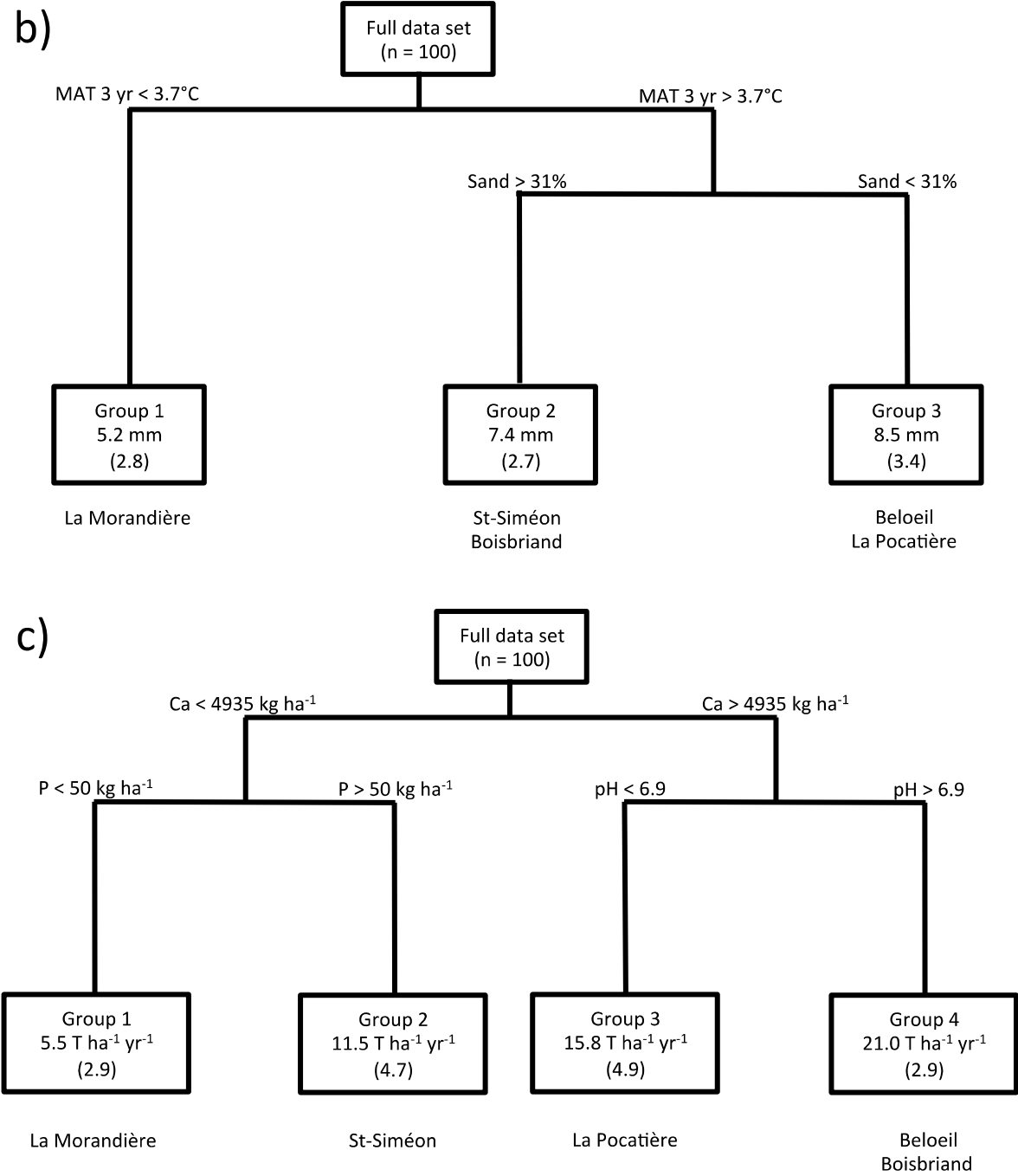

Figure 6. Regression tree model for stem height (a), stem diameter (b), and biomass yield (c) in the three-year rotation willow SRC. Ca, soil exchangeable calcium; Clay, soil clay content; MAT, mean annual temperature; $\mathrm{P}$, soil extractible phosphorus; $\mathrm{pH}$, soil $\mathrm{pH}$; Sand, soil sand content. Splitting values are indicated along the branches, and boxes indicate terminal node mean ( \pm standard error). 


\section{Discussion}

Willow SRC plantations have been studied for a number of years in many temperate and boreal regions of the world. Previous studies carried out on willows in short-rotation coppice showed that the climate of south-eastern Canada offers favourable growing conditions [26,27]. In the current study, the annualized diametric growth of willow was significantly affected by both cultivar and site in the two-year rotation and only by the cultivar in the three-year rotation, with the best performing cultivars all belonging to the same $S$. miyabeana cultivar group. With respect to height increment, we found that site played a significant role (at least for some cultivars) in determining performance. In any case, since diameter and height play a major role in determining the total woody biomass of the plant at the end of each growing season, biomass of the willow plants varied significantly according to site $(p<0.0001)$ and cultivar $(p<0.0001)$. Strong genetic, site, and genetic by site interactions have previously been observed in other experiments carried out in willow SRC [28]. In some cases, site quality differences were most likely driven by nutrient concentration, physical traits, and water holding capacity of the soil [29], whereas in others, differences were mainly influenced by climatic variables, such as growing degree-days [30] or total rainfall during the growing season [31]. Likewise, plant genetics has been shown to play an important role in determining the biomass yield of willow SRC, both under optimal [32] and harsh [33] growing conditions. In our study, the lowest biomass yield was shown by cultivar '5027', which is consistent with previous results published for Canada [34], and reveals once again the poor performance of $S$. viminalis cultivars in such regions. Even though this result is surprising, considering that the most productive willow cultivars in other suitable regions do originate from S. viminalis [35], its poor performance in our study is likely due to its high sensitivity to pests and diseases, including the willow leaf beetle (Plagiodera versicolora Laicharteg.) and potato leafhopper (Empoasca fabae Harris). On the other hand, our results confirm the high performance of S. miyabeana cultivars also reported in other studies [36]. This species offers a wide range of genetic material for farmers to select from for probable successful willow growth in SRC for commercial purposes in Quebec; breeders, too, can select from among new high-performing commercial varieties. Intriguingly, we also found a significant interaction between rotation length and site $(p<0.0001)$. This finding could have a very strong impact on the management of willow SRC plantations. In fact, if the ultimate goal of willow SRC is to maximize annual yield, our study shows that in some cases a two-year rotation would be preferable to a three-year cycle. In general, willow SRC plantations show higher annual biomass yield in longer, rather than shorter, rotation cycles [24] and specifically triennial harvesting has been shown to provide higher annual biomass production than biennial harvesting [37]. On the basis of these observations, the explanation for this differentiated response should be sought elsewhere. Actually, the differences in the two rotations observed in the current study were evident in both very suitable (i.e., Boisbriand and La Pocatière) and harsher (i.e., La Morandière and St-Siméon) growing sites. In this case, the only factor that seemed to differentiate these groups of sites was P soil concentration, which was significantly higher (average $75.5 \mathrm{~kg} \mathrm{ha}^{-1}$ ) in those where the highest biomass yield was recorded in the two-year rotation (i.e., La Pocatière and St-Siméon) and lower (average $20 \mathrm{~kg} \mathrm{ha}^{-1}$ ) where the highest biomass yield was recorded for most cultivars in the three-year rotation (i.e., Boisbriand and La Morandière). The fact that the only site where biomass yield was rather stable showed an intermediate P soil concentration (average $30 \mathrm{~kg} \mathrm{ha}^{-1}$ ) could support this observation. In fact, some researchers have shown that the concentration of nutrients in the soil (including fertilization to enhance this pool) affects the mean annual increment (MAI) of some short-rotation forestry species, including poplar and sycamore [38].

The fact remains that the annual yield values reported for most of the cultivars on the La Pocatière site are surprisingly high. Yet the climatic conditions of this site are far from the most favourable among these experimental sites. The average annual degree days $\left(>5^{\circ} \mathrm{C}\right)$ in La Pocatière are 1582 , compared to 2029 in Boisbriand and 2122 in Beloeil. Soil characteristics, in particular the high percentage of organic matter, certainly contribute to higher yield. Very high yield was also reported by Héneault-Éthier [39] for willow, S. miyabeana 'SX64', grown in riparian buffer strips on organic rich soils in southern Quebec. 
When data concerning cultivars were pooled, some soil (i.e., extractible P concentration) and meteorological (i.e., mean annual temperature) factors in the two-year rotation and soil exchangeable $\mathrm{Ca}$, extractible $\mathrm{P}$ and $\mathrm{pH}$ in the three-year rotation were the best predictors of annual biomass yield. This information is partially consistent with the results of a recent published study in which silt content, soil organic matter, $\mathrm{pH}$, exchangeable $\mathrm{Ca}$ and $\mathrm{Mg}$, and total $\mathrm{N}$ and $\mathrm{Zn}$ were significantly and positively related to aboveground yield of willow in SRC [23]. In fact, in acid soils, soluble inorganic $P$ is fixed by aluminum and iron, thereby reducing its availability for the crop [40]. This would explain the strong dependence of willow biomass yield and $\mathrm{pH}$ and $\mathrm{Ca}$.

\section{Conclusions}

Taken together, our findings show that most commercial willow cultivars can be grown in short rotation coppice and achieve high biomass yields under most of Quebec's pedoclimatic conditions. However, care should be taken to both avoid choosing poor performing genetic material (e.g., S. viminalis '5027') and match the right cultivar with the right environmental conditions. In particular, since there is evidence that soil variables (i.e., $\mathrm{pH}$, soil extractible $\mathrm{P}$ and $\mathrm{Ca}$ ) have a stronger impact than climate variables on willow growth and productivity, the site on which the crop will be grown should be selected with care, and site soil should be modified to decrease physico-chemical imbalances (e.g., liming) that prevent good crop development.

Author Contributions: M.L. conceived and designed the experiment; M.L. and B.L. supervised the experiments and the samplings; B.L. and W.G.N. analyzed the data; W.G.N. wrote the first draft of the paper; B.L. and M.L. provided extensive proof-reading and suggested edits.

Acknowledgments: This study was supported by CÉROM (Seed Research Center) and funded by the RPBQ (Quebec Bio-industrial Crop Network) of the Quebec Ministry of Agriculture, Fisheries and Food.

Conflicts of Interest: The authors declare no conflict of interest.

\section{References}

1. Hinchee, M.; Rottmann, W.; Mullinax, L.; Zhang, C.; Chang, S.; Cunningham, M.; Pearson, L.; Nehra, N. Short-rotation woody crops for bioenergy and biofuels applications. In Vitro Cell. Dev. Biol. Plant 2009, 45, 619-629. [CrossRef] [PubMed]

2. Drew, A.P.; Zsuffa, L.; Mitchell, C.P. Terminology relating to woody plant biomass and its production. Biomass 1987, 12, 79-82. [CrossRef]

3. Auclair, D.; Bouvarel, L. Intensive or extensive cultivation of short rotation hybrid poplar coppice on forest land. Bioresour. Technol. 1992, 42, 53-59. [CrossRef]

4. Kenney, W.A.; Sennerby-Forsse, L.; Layton, P. A review of biomass quality research relevant to the use of poplar and willow for energy conversion. Biomass 1990, 21, 163-188. [CrossRef]

5. Sims, R.E.H.; Senelwa, K.; Maiava, T.; Bullock, T. Eucalyptus species for biomass energy in Nex Zealand-I: Growth screening trials at first harvest. Biomass Bioenergy 1999, 16, 199-205. [CrossRef]

6. Grünewald, H.; Böhm, C.; Quinkenstein, A.; Grundmann, P.; Jörg Eberts, J.; von Wühlisch, G. Robinia pseudoacacia L.: A Lesser Known Tree Species for Biomass Production. Bioenergy Res. 2009, 2, 123-133. [CrossRef]

7. Rytter, L.; Šlapokas, T.; Granhall, U. Woody biomass and litter production of fertilized grey alder plantations on a low-humified peat bog. For. Ecol. Manag. 1989, 28, 161-176. [CrossRef]

8. Lopez, F.; Garcia, M.M.; Ynez, R.; Tapias, R.; Fernàndez, M.; Diaz, M.J. Leucaena species valoration for biomass and paper production in 1 and 2 year harvest. Bioresour. Technol. 2008, 99, 4846-4853. [CrossRef] [PubMed]

9. Mitchell, C.P. Ecophysiology of short rotation forest crops. Biomass Bioenergy 1992, 2, 25-37. [CrossRef]

10. Dimitriou, I.; Baum, C.; Baum, S.; Busch, G.; Schulz, U.; Köhn, J.; Lamersdorf, N.; Leinweber, P.; Aronsson, P.; Weih, M.; et al. The impact of Short Rotation Coppice (SRC) cultivation on the environment. vTI Agric. For. Res. 2009, 59, 159-162. 
11. Park, B.B.; Yanai, R.D.; Sahm, J.M.; Ballard, B.D.; Abrahamson, L.P. Wood Ash Effects on Soil Solution and Nutrient Budgets in A Willow Bioenergy Plantation. Water Air Soil Pollut. 2004, 159, 209-224. [CrossRef]

12. Labrecque, M.; Teodorescu, T.I.; Daigle, S. Biomass productivity and wood energy of salix species after 2 years growth in SRIC fertilized with wastewater sludge. Biomass Bioenergy 1997, 12, 409-417. [CrossRef]

13. Guidi Nissim, W.; Cincinelli, A.; Martellini, T.; Alvisi, L.; Palm, E.; Mancuso, S.; Azzarello, E. Phytoremediation of sewage sludge contaminated by trace elements and organic compounds. Environ. Res. 2018, 164, 356-366. [CrossRef] [PubMed]

14. Cavanagh, A.; Gasser, M.O.; Labrecque, M. Pig slurry as fertilizer on willow plantation. Biomass Bioenergy 2011, 35, 4165-4173. [CrossRef]

15. Guidi Nissim, W.; Voicu, A.; Labrecque, M. Willow short-rotation coppice for treatment of polluted groundwater. Ecol. Eng. 2014, 62, 102-114. [CrossRef]

16. Dimitriou, I.; Aronsson, P. Wastewater and sewage sludge application to willows and poplars grown in lysimeters-Plant response and treatment efficiency. Biomass Bioenergy 2011, 35, 161-170. [CrossRef]

17. Börjesson, P.; Berndes, G. The prospects for willow plantations for wastewater treatment in Sweden. Biomass Bioenergy 2006, 30, 428-438. [CrossRef]

18. Guidi Nissim, W.; Pitre, F.E.; Teodorescu, T.I.; Labrecque, M. Long-term biomass productivity of willow bioenergy plantations maintained in southern Quebec, Canada. Biomass Bioenergy 2013, 56, 361-369. [CrossRef]

19. Amichev, B.Y.; Hangs, R.D.; Konecsni, S.M.; Stadnyk, C.N.; Volk, T.A.; Bélanger, N.; Vujanovic, V.; Schoenau, J.J.; Moukoumi, J.; Van Rees, K.C.J. Willow Short-Rotation Production Systems in Canada and Northern United States: A Review. Soil Sci. Soc. Am. J. 2014, 78, S168-S181. [CrossRef]

20. Lafleur, B.; Lalonde, O.; Labrecque, M. First-Rotation Performance of Five Short-Rotation Willow Cultivars on Different Soil Types and Along a Large Climate Gradient. BioEnergy Res. 2017, 10, 158-166. [CrossRef]

21. Grime, J.P. Plant Strategies and Vegetation Processes; John Wiley \& Sons, Ltd.: Chichester, UK; New York, NY, USA; Brisbane, Australia; Toronto, ON, Cadana, 1979.

22. Fontana, M.; Labrecque, M.; Messier, C.; Courchesne, F.; Bélanger, N. Quantifying the effects of soil and climate on aboveground biomass production of Salix miyabeana SX67 in Quebec. New For. 2017, 48, 817-835. [CrossRef]

23. Fontana, M.; Labrecque, M.; Messier, C.; Bélanger, N. Permanent site characteristics exert a larger influence than atmospheric conditions on leaf mass, foliar nutrients and ultimately aboveground biomass productivity of Salix miyabeana 'SX67'. For. Ecol. Manag 2018, in press. [CrossRef]

24. Willebrand, E.; Ledin, S.; Verwijst, T. Willow coppice systems in short rotation forestry; effects of plant spacing, rotation length and clonal disposition on biomass production. Biomass Bioenergy 1993, 4, 323-331. [CrossRef]

25. Breiman, L.; Friedman, J.H.; Olshen, R.A.; Stone, C.J. Classification and Regression Trees; Chapman and Hall/CRC: Boca Raton, FL, USA, 1998.

26. Labrecque, M.; Teodorescu, T.I. Field performances and biomass production of 12 willow and poplar clones in short-rotation coppice in southern Quebec (Canada). Biomass Bioenergy 2005, 29, 1-9. [CrossRef]

27. Guidi, W.; Pitre, F.E.; Labrecque, M. Short-Rotation Coppice of Willows for the Production of Biomass in Eastern Canada. In Biomass Now—Sustainable Growth and Use; Matovic, M.D., Ed.; InTech: London, UK, 2013; Chapter 17; pp. 421-448.

28. Larsen, S.; Jørgensen, U.; Lærke, P.E. Willow Yield Is Highly Dependent on Clone and Site. BioEnergy Res. 2014, 7, 1280-1292. [CrossRef]

29. Mosseler, A.; Major, J.E.; Labrecque, M. Genetic by environment interactions of two North American Salix species assessed for coppice yield and components of growth on three sites of varying quality. Trees 2014, 28, 1401-1411. [CrossRef]

30. Fabio, E.S.; Volk, T.A.; Miller, R.O.; Serapiglia, M.J.; Gauch, H.G.; Van Rees, K.C.J.; Hangs, R.D.; Amichev, B.Y.; Kuzovkina, Y.A.; Labrecque, M.; et al. Genotype $\times$ environment interaction analysis of North American shrub willow yield trials confirms superior performance of triploid hybrids. GCB Bioenergy 2016, 9, 445-459. [CrossRef]

31. Aylott, M.J.; Casella, E.; Tubby, I.; Street, N.R.; Smith, P.; Taylor, G. Yield and spatial supply of bioenergy poplar and willow short, rotation coppice in the UK. New Phytol. 2008, 178, 358-370. [CrossRef] [PubMed] 
32. Wilkinson, J.M.; Evans, E.J.; Bilsborrow, P.E.; Wright, C.; Hewison, W.O.; Pilbeam, D.J. Yield of willow cultivars at different planting densities in a commercial short rotation coppice in the north of England. Biomass Bioenergy 2007, 31, 469-474. [CrossRef]

33. Grenier, V.; Pitre, F.E.; Guidi Nissim, W.; Labrecque, M. Genotypic differences explain most of the response of willow cultivars to petroleum-contaminated soil. Trees 2015, 29, 871-881. [CrossRef]

34. Mosseler, A.; Major, J.E. Coppice growth responses of two North American willows in acidic clay soils on coal mine overburden. Can. J. Plant Sci. 2014, 94, 1269-1279. [CrossRef]

35. Stolarski, M.; Szczukowski, S.; Tworkowski, J.; Klasa, A. Productivity of seven clones of willow coppice in annual and quadrennial cutting cycles. Biomass Bioenergy 2008, 32, 1227-1234. [CrossRef]

36. Thevathasan, N.; Coleman, B.; Zabek, L.; Ward, T.; Gordon, A. Agroforestry in Canada and its Role in Farming Systems. In Temperate Agroforestery Systems, 2nd ed.; Gordon, A., Newman, S.M., Coleman, B., Eds.; CABI: London, UK, 2018; Chapter 2; pp. 7-49.

37. Kopp, R.F.; Abrahamson, L.P.; White, E.H.; Burns, K.F.; Nowak, C.A. Cutting cycle and spacing effects on biomass production by a willow clone in New York. Biomass Bioenergy 1997, 12, 313-319. [CrossRef]

38. Coyle, D.R.; Aubrey, D.P.; Coleman, M.D. Growth responses of narrow or broad site adapted tree species to a range of resource availability treatments after a full harvest rotation. For. Ecol. Manag. 2016, 362, 107-119. [CrossRef]

39. Hénault-Ethier, L.; Gomes, M.P.; Lucotte, M.; Smedbol, É.; Maccario, S.; Lepage, L.; Juneau, P.; Labrecque, M. High yields of riparian buffer strips planted with Salix miyabena 'SX64' along field crops in Québec, Canada. Biomass Bioenergy 2017, 105, 219-229. [CrossRef]

40. Adnan, A.; Mavinic, D.S.; Koch, F.A. Pilot-scale study of phosphorus recovery through struvite crystallization-examining to process feasibility. J. Environ. Eng. Sci. 2003, 2, 315-324. [CrossRef]

(C) 2018 by the authors. Licensee MDPI, Basel, Switzerland. This article is an open access article distributed under the terms and conditions of the Creative Commons Attribution (CC BY) license (http:/ / creativecommons.org/licenses/by/4.0/). 